\title{
The Relation between Self-Efficacy and Group Cohesiveness Perceptions of Professional Men and Woman's Football Team (Ankara Province Example)
}

\author{
Faruk Aydin ${ }^{1}$, Hakan Sunay ${ }^{2}$, Erdal Bal ${ }^{3}$, Erdem Ayyildiz ${ }^{2}$ \\ ${ }^{1}$ Faculty of Sport Sciences, Lokman Hekim University, Turkey \\ ${ }^{2}$ Faculty of Sports Sciences, Ankara University, Turkey \\ ${ }^{3}$ Faculty of Life Sciences, Health Sciences University, Turkey
}

Received November 6, 2019; Revised December 28, 2019; Accepted December 30, 2019

Copyright $\odot 2020$ by authors, all rights reserved. Authors agree that this article remains permanently open access under the terms of the Creative Commons Attribution License 4.0 International License

\begin{abstract}
The Purpose of the study is to determine whether there is a meaningful difference between the self-efficacy and self-efficacy perceptions of the footballers (gender, marital status, age and education level etc.) according to their personal qualities. The sample of the work consists of professional male and female soccer teams in Ankara. A total of 354 athletes from 10 male to 5 female soccer teams participated in the study. 128 female soccer players and 226 male soccer players participated. The majority of the athletes participating in the survey are between the ages of 19-23. "Group Cohesion Scale" developed by Hatem Ocel and Orhan Aydin (2006) and " General Self-Efficacy Scale" developed by Aysin Yesilay, Ralf Shcwarzer and Matthias Gersusalem (1995) were used in the research. Because of the obtained data did not show normal distribution, the nonparametric tests Mann Whitney $\mathrm{U}$ and Kruskal Wallis test statistics were used. According to the findings, "Group Cohesion and Self-Efficacy" perceptions differ significantly according to gender. Male participants $(X=2,26)$ were found to have a higher "Group Cohesion" score than female participants $(X=2,08)$. It is also seen that male participants $(X=2,14)$ received "Self-Efficacy" scores higher than female participants $(\mathrm{X}=$ 1.96). According to the marital status variable, there was no significant difference in the perception of "Group Cohesion" and "Self-Efficacy". There was a significant difference between "Group Cohesion" scores according to age variable. As a result of the multiple comparison tests, the 15-18 age groups were found to score higher than the age group of 19 and above. According to the educational status variable, there was no significant difference between the scale scores of "Group Cohesion and Self-Efficacy".
\end{abstract}

Keywords Cohesion, Football, Self-Efficacy

\section{Introduction}

In our developing world, football has ceased to be a game and has become an industry. In this industry, various studies have been carried out to determine the group fit and self-perception of the athletes in the teams. When the matches played on the team sports during the season are evaluated, it can be seen that the athletes who have discrepancies in the team at different times during the season do not feel compatible with the group or do not consider themselves sufficient. Players sometimes act independently, not with the team. Sometimes they have to show individual reflexes, but they make false reflexes by caring about team integrity. (Durdubas, 2013). One of the reasons behind all of this was the realization of self-efficacy and team harmony among the athletes. (Loughead and Hardy, 2006; Cox, 2007). Achieving the expected level of team performance depends on the team moving together as a whole. It is seen that team wrappiness researches have increased with the approaches regarding the continuation of the exhibited sporting performance. In team sports, revealing the relationship between group wrappiness and self-efficacy is important in terms of ensuring team integrity and group dynamics. Group Coiling: Cohesion means latching together to form a tight bond. (Dion, 2000). Self-efficacy is defined as kapas the capacity of an individual to organize and perform the activities necessary to achieve a certain performance" (Bandura 1997). Self-efficacy perception directly affects the individual's choice of activity, the level of effort to be spent, and the success level. (Senemoglu, 1997; Askar and Umay, 2001; Önen ve Öztuna, 2005; Orhan ve Akkoyunlu, 2003; Bıkmaz, 2004). Self-efficacy in sports sciences can mean that an athlete is able to perform his skills in the best way during competition and outperform his opponent's 
performance (Feltz, Short, ve Sullivan, 2008). The aim of this study is to investigate the self-efficacy and coarseness perceptions of male and female football players according to their personal characteristics (gender, marital status, age and educational level, etc.).

\section{Method}

Descriptive method was used in the research. The descriptive method is a situation that demonstrates the present situation. The data were applied to 10 professional male and 5 female football team athletes in Ankara between January 2017 and June 2017. The scope of the research; Professional male and female football teams in Ankara consist of athletes (10 men and 5 women). The average 25 licensed players of each team are on the team lists (tff.com.tr-aaskf.org.tr). In this case, approximately 250 football players from 10 men's teams and approximately 130 football players from 5 women's teams constitute the scope of the research (tff.com.tr-aaskf.org.tr). Since the entire scope was intended to be reached, no sample was taken. In the study participated 226 male and 128 female football players the distribution of the participants according to demographic variables is shown in Table 1.

Table 1. Frequency and Percentage Distributions of Socio-Demographic Variables

\begin{tabular}{|c|c|c|c|}
\hline \multicolumn{2}{|c|}{ Demographic Variables } & f & $\%$ \\
\hline \multirow{4}{*}{ Age } & $15-18$ & 97 & 27,4 \\
\hline & $19-23$ & 156 & 44,1 \\
\hline & $24-29$ & 80 & 22,6 \\
\hline & 30 and above & 21 & 5,9 \\
\hline \multirow{2}{*}{ Gender } & Male & 226 & 63,8 \\
\hline & Female & 128 & 36,2 \\
\hline \multirow{2}{*}{ Marital status } & The maried & 45 & 12,7 \\
\hline & Single & 309 & 87,3 \\
\hline \multirow{3}{*}{ Education status } & Primary education & 254 & 71,8 \\
\hline & Associate degree & 28 & 7,9 \\
\hline & Lisance (undergraduate) & 72 & 20,3 \\
\hline \multirow{15}{*}{ The teams } & Fomget (female) & 30 & 8,5 \\
\hline & Mengü (female) & 30 & 8,5 \\
\hline & Çankaya Gençlik (female) & 26 & 7,3 \\
\hline & Ankara Metropol (female) & 27 & 7,6 \\
\hline & Gölbaşı Belediye (female) & 13 & 3,7 \\
\hline & KahramanKazan(Bugsaş)(male) & 20 & 5,6 \\
\hline & Ankara Adliye (male) & 22 & 6,2 \\
\hline & Keçiörengücü (male) & 22 & 6,2 \\
\hline & Etimesgut Belediye (male) & 25 & 7,1 \\
\hline & Ankaragücü (male) & 21 & 5,9 \\
\hline & Hacettepe (male) & 24 & 6,8 \\
\hline & Ankara Demir (male) & 21 & 5,9 \\
\hline & Gençlerbirliği (male) & 21 & 5,9 \\
\hline & Altındağ Belediye (male) & 30 & 8,5 \\
\hline & Osmanlıspor (male) & 22 & 6,2 \\
\hline TOTAL & & 354 & 100 \\
\hline
\end{tabular}


As seen in Table 1; 128 female football players and 226 male football players in total 354 athletes participated in the study. 156 (44.1\%) players between the ages of 19-23, 80 (22.6\%) between the ages of 24-29, 21 (5.9) players over the age of 30 participated in the study. It was understood that $45(12.7 \%)$ of the participants were married and 309 (87.3\%) were single. It was found that 254 (71.8\%) of the athletes had first education level (primary, secondary, high school), 28 (7.9\%) had associate degree and 72 (20.3\%) had undergraduate education. It was learned that 17 (4.8\%) of the athletes were public servants, 57 (16.1\%) were self-employed, 265 (74.9\%) students and 6 (1.7\%) were unemployed.

Data collection tool; in the study, Carron et al. (1998), developed by Hatem Ocel and Orhan Aydın (2009) "Group Cohesion Scale“ "The Group Cohesion Scale", which was adapted to Turkish, was used. The scale has four winding dimensions. 1. Group integration in the task (5 items), 2. Group integration in the social (4 items), 3. Group socially attractive level (5 items), 4. Group task finding level (4 items) total of 18 sub-scales. In addition to the four subscale scores, one general scoring score is obtained. Author permission was obtained from the authors via e-mail. In the study, a 4-point Likert-type scale was applied and internal consistency was calculated again.

General Self-Efficacy Scale developed by Yesilay (2010) was used to collect other quantitative data. "The Generalized Self-Efficacy Scale” is a 4-point Likert-type scale consisting of 10 items. In the introductory information form, there are questions regarding the gender, marital status, age, occupation and educational status of the athletes who will participate in the study. Cronbach's Alpha $(\alpha)$ internal consistency coefficients related to the sub-dimensions of the scales applied to the players in order to examine the relationship between self-efficacy and perceptions of professional football teams of Ankara Province. 71, For the self-efficacy scale, 92 were determined. According to Kayıs, the reliability of the scales is interpreted as follows based on Cronbach's Alpha $(\alpha)$ coefficient:

The scale is not reliable if $0.00 \leq a<0.40$.

The scale reliability is low if $0.40 \leq \mathrm{a}<0.60$.

The scale reliability is reliable if $0.60 \leq \mathrm{a}<0.80$.

Scale reliability is high if $0.80 \leq \mathrm{a}<1,0$ (Kayıs, 2006).

Analysis of Data; As a result of the normality analysis tests, it was found that the data were not distributed normally and therefore Mann-Whitney U method for the dual groups (gender and marital status) and Kruskall Wallis method for the multiple groups (age, education levels and occupational groups) tests were applied.

\section{Findings}

The results of the Whit Mann Whitney U test performed according to the gender variability related to the perception of Group Wrestling and the self-efficacy of the players participating in the study are given in Table 2.

As shown in Table 2, a significant difference $(\mathrm{U}=10487.0 \mathrm{p}<0.05)$ was found as a result of the "Mann Whitney U" test performed to football players according to the gender variable related to the perception of "Group Cohesion". Considering the rank averages, it was seen that male participants $(X=2.26)$ had higher "Group Cohesion" points than female participants ( $\mathrm{X}=2.08)$. 'According to the Whit Mann Whitney U' 'test performed on football players according to gender variable related to self-efficacy perception, a significant difference was found ( $\mathrm{U}=12295.0$ $\mathrm{p}$ <0.05). 'When the rank averages are taken into consideration, it is seen that male participants $(X=2.14)$ have higher self-efficacy scores than female participants $(\mathrm{X}=1.96)$.

As can be seen in Table 3, Mann Whitney U test applied to the participants according to the marital status variable related to Group Cohesion and Self-Efficacy scales did not reveal a significant difference in Group Cohesion and Self-Efficacy perception.

Table 2. Mann Whitney U Test Results According to Gender Variable for Double Groups

\begin{tabular}{|c|c|c|c|c|c|c|c|}
\hline Scale & Gender & $\mathbf{N}$ & $\mathrm{X}$ & Rank Average & Row Total & $\mathbf{U}$ & $\mathbf{P}^{*}$ \\
\hline \multirow{2}{*}{ Group Cohesion } & Male & 226 & 2,26 & 195,1 & 44092,0 & \multirow{2}{*}{10487,0} & \multirow{2}{*}{, $000 *$} \\
\hline & Female & 128 & 2,08 & 146,4 & 18743,0 & & \\
\hline \multirow{2}{*}{ Self-efficacy } & Male & 226 & 2,14 & 187,1 & 42284,0 & \multirow{2}{*}{12295,0} & \multirow{2}{*}{, $019^{*}$} \\
\hline & Female & 128 & 1,96 & 160,5 & 20551,0 & & \\
\hline
\end{tabular}

$*(\mathrm{P}<0,05)$

Table 3. Mann Whitney U Test Results According to Marital Status Variable

\begin{tabular}{|c|c|c|c|c|c|c|c|}
\hline Scale & Marital Status & $\mathbf{N}$ & $\mathbf{X}$ & Rank Average & Row Total & $\mathbf{U}$ & $\mathbf{P}^{*}$ \\
\hline \multirow{2}{*}{ Group Cohesion } & Maried & 45 & 2,18 & 172,7 & 7775,5 & \multirow{2}{*}{6740,5} & \multirow{2}{*}{,741 } \\
\hline & Single & 309 & 2,20 & 178,1 & 55059,5 & & \\
\hline \multirow{2}{*}{ Self-efficacy } & Maried & 45 & 2,02 & 165,7 & 7458,0 & \multirow{2}{*}{6423,0} & \multirow{2}{*}{ 408 } \\
\hline & Single & 309 & 2,09 & 179,2 & 55377,0 & & \\
\hline
\end{tabular}


Table 4. Kruskall Wallis Test Statistics by age variable

\begin{tabular}{|c|c|c|c|c|c|c|c|}
\hline Scale & Age & $\mathbf{N}$ & Rank Average & sd & $\mathrm{X}^{2}$ & $\mathbf{P}^{*}$ & $\begin{array}{c}\text { Difference Model } \\
\text { Viewer }\end{array}$ \\
\hline \multirow{4}{*}{ Group Cohesion } & $15-18$ & 97 & 198,1 & \multirow{4}{*}{3} & \multirow{4}{*}{10,2} & \multirow{4}{*}{, $017^{*}$} & \multirow{4}{*}{$15-18>19$ and above } \\
\hline & $19-23$ & 156 & 159,3 & & & & \\
\hline & $24-29$ & 80 & 190,1 & & & & \\
\hline & 30 and above & 21 & 168,6 & & & & \\
\hline \multirow{4}{*}{ Self-efficacy } & $15-18$ & 97 & 193,6 & \multirow{4}{*}{3} & \multirow{4}{*}{3,5} & \multirow{4}{*}{,314 } & \multirow{4}{*}{-} \\
\hline & $19-23$ & 156 & 170,0 & & & & \\
\hline & $24-29$ & 80 & 175,5 & & & & \\
\hline & 30 and above & 21 & 165,7 & & & & \\
\hline
\end{tabular}

$*(\mathrm{P}<0,05)$

Table 5. Test Statistics Results by Kruskall Wallis Education variable

\begin{tabular}{|c|c|c|c|c|c|c|c|}
\hline Scale & Education variable & $\mathbf{N}$ & Rank Average & sd & $X^{2}$ & $\mathbf{P}^{*}$ & Difference \\
\hline \multirow{3}{*}{ Group Cohesion } & primary, secondary, high school & 254 & 174,6 & \multirow{3}{*}{2} & \multirow{3}{*}{0,7} & \multirow{3}{*}{,673 } & \multirow{3}{*}{ - } \\
\hline & associate degree & 28 & 189,6 & & & & \\
\hline & undergraduate education & 72 & 182,8 & & & & \\
\hline \multirow{3}{*}{ Self-efficacy } & primary, secondary, high school & 254 & 183,3 & \multirow{3}{*}{2} & \multirow{3}{*}{3,1} & \multirow{3}{*}{,203 } & \multirow{3}{*}{ - } \\
\hline & associate degree & 28 & 154,0 & & & & \\
\hline & undergraduate education & 72 & 166,1 & & & & \\
\hline
\end{tabular}

$*(\mathrm{P}<0,05)$

As can be seen in Table 4, a significant difference was found as a result of Kruskall-Wallis analysis on the perception of "Group Cohesion". [ $\mathrm{x}^{2}(\mathrm{sd}=3, \mathrm{n}=354)=10,2$, $\mathrm{p}<0,05]$. According to the results of the "Difference Model Viewer" test multiple comparison tests to determine which age group the meaningful differences were caused, it was observed that the 15-18 age groups scored higher than the 19 and older age group. Kruskall Wallis test statistic was used to determine whether the difference between the self-efficacy and wounding perceptions of the players according to their educational status is significant. The results obtained are shown in Table 5.

As can be seen in Table 5, according to the in Group Cohesion and Self-Efficacy scales, us Kruskall Wallis analysis was applied to athletes and no significant difference was found in the perception of Group Cohesion and Self-Efficacy.

Table 6. Scale Correlation Values

\begin{tabular}{|c|c|c|c|}
\hline & & $\begin{array}{c}\text { Group } \\
\text { Cohesion }\end{array}$ & Self-efficacy \\
\hline \multirow{4}{*}{$\begin{array}{c}\text { Group } \\
\text { Cohesion }\end{array}$} & Spearman's Rho & 1,000 &, 064 \\
\cline { 2 - 4 } & Sig. (2-Tailed) & &, 227 \\
\cline { 2 - 4 } & $\mathbf{N}$ & 354 & 354 \\
\hline \multirow{3}{*}{ Self-efficacy } & Spearman's Rho &, 064 & 1,000 \\
\cline { 2 - 4 } & Sig. (2-Tailed) &, 227 & \\
\cline { 2 - 4 } & $\mathbf{N}$ & 354 & 354 \\
\hline
\end{tabular}

Correlation coefficient of 1.00 is an excellent positive relationship, -1.00 is an excellent negative relationship;
0.00 being indicates that there is no relationship. The absolute value of the correlation coefficient is between $0.70-1.00$ high, and between $-0.70-0.30$ is medium; $0.30-0.00$ can be defined as a low level relationship (Buyukozturk, 2019). In this sense when the results of the analysis were examined, it was found that there was no significant relationship between group cohesion and self-efficacy perception scores of the participants $(r=, 064$, $\mathrm{p}<.05)$.

\section{Discussion and Conclusions}

In this section, the results obtained in relation to the Scales and Self-Efficacy Scales applied in January 2017-June 2017 on 10 male and 5 female football teams male and female athletes in Ankara are discussed. According to Mullen and Copper (1994) and Carron, Colman and Wheeler (2002) meta-analyzes have shown that winning will have a positive impact on performance. It was observed that self-efficacy belief did not contribute to predicting the perceptions of the teams about the current success of their teams. The perception of self-efficacy is actually a concept that was put forward to indicate the beliefs of individuals in their capacities. Accordingly, it comes to the agenda when it comes to individuals rather than groups that are verified in terms of performance and perceptions about performance. In our study, perceptions about the success of the group, not individual successes were emphasized. Thus, the perception of self-efficacy beliefs regarding the success of the group not to make any 
contribution on routines is not surprising.

Self-efficacy belief can be reduced when the individual is confronted with a disagreeable situation. In other words, a player who doesn't trust his talents will stop fighting the problems that will arise during the match, and the player who believes in his talents will struggle to overcome this challenge more. According to Ocal and Aydin (2009), there is a positive relationship between the beliefs of individuals about their ability to succeed and the actual performance of group members (Ocal and Aydın 2009). The high competence belief of the players has a positive effect on the motivation levels by increasing their efforts to reach the goal, while having a low competence belief has a negative effect on the motivation levels of the players. In this respect, it can be said that the general self-efficacy levels of the players should be high and this will contribute to the success of the team.

The success / failure and performance level of the teams in team sports is one of the most important research topics in sports psychology. Perceptions such as group coarseness and competence significantly affect success and performance. Emotional intimacy occurs both in the team and outside the team in the relations between the athletes in teams with high bandages. This is an important factor in increasing team performance and success. In the case of low winding, it is thought to be the opposite. In the study we conducted regarding whether the teams are wrapped or not, the group wrestling and competence perceptions were examined according to the demographic characteristics of the athletes involved in the team, and it is also important to reveal the reasons of the bondings in the studies to be discussed.

Belief in self-efficacy indicates how long the individual is able to face these difficulties when confronted with an unfavorable situation with the strength of struggle, effort initiative and persistence. According to many researchers, there is a positive relationship between the beliefs of individuals about their ability to succeed and the actual performance of group members. (Ocel and Aydin 2009). In this respect, it can be said that the general self-efficacy levels of the players should be high and this will contribute to the success of the team.

It was found that the relationship between group cohesion and self-efficacy of the football players participating in the study was not significant (Table 6). Spink (1990) in his research on group cohesion in volleyball teams. It is stated that the relationship between group cohesion and self-efficacy is not significant in terms of team performance of professional volleyball teams.

The results of this study showed that the general self-efficacy of the players was moderate and the initiative average score from the self-efficacy was higher than the mean of the effort and persistence sub-dimensions. In addition, general self-efficacy in footballers was influenced by age.

It was observed that self-efficacy belief did not contribute to predicting the perceptions of the teams about the current success of their teams. The perception of self-efficacy is actually a concept put forward to point out the beliefs of individuals to their capacities. In our study, perceptions about the success of the group, not individual successes were emphasized. Thus, it is not surprising that self-efficacy belief does not contribute to predicting perceptions of group success. Yildırım and İlhan (2010); Usher L.E., Pajares F. (2008). found that general self-efficacy did not change in relation to age. On the other hand; Alpay (2010), 69 Adapting the General Self-Efficacy Scale (GSES) into Turkish"study, on a total of 693 university students (377 female and 316 male) aged between 17 and 39 years. Found that the scores of the students' General Self-Efficacy Scale (GSES) were higher than those of the students between the ages of 17-20. These results are similar to the research results. On the other hand Basoğlu (2017) 36 Greco-Roman Star Male Wrestling National Team players between the ages of 15-17 in the study of achievement perception and self-efficacy levels were examined. The achievement perception and self-efficacy scores of the stars male wrestlers in the study were found to be lower than the average. This finding may be due to sports branch differences.

\section{REFERENCE}

[1] Alpay, A. (2010). 'General Self-Efficacy Scale GSES Turkish Adaptation Study, Inonu University Journal of Education Faculty, 11(2), 113-131. Malatya.

[2] Askar, P. and Umay A. (2001). Computer mathematics self-efficacy perception of elementary school mathematics teachers, Hacettepe University Journal of Education Faculty, , 21,1-8.

[3] Bandura A. (1997). Social foundations of thought and action: A social cognitive theory. Englewood Cliffs, NJ: Prentice Hall.

[4] Basoğlu B., (2017). Grekoromen Yıldız Erkek Güreş Milli Takım Oyuncularının Başarı Algısı ve Özyeterlilik Düzeylerinin İncelenmesi, GaziAntep Üniversitesi Spor Bilimleri Dergisi, 2(1), 31-40.

[5] Bikmaz, F. H. (2004) "Validity and Reliability Study of Self-Efficacy _ Belief Scale in Primary School Teachers' Science Teaching", Journal of National Education. Say1 161, 10.11.2017 tarihinde http://yayim.meb.gov.tr/dergiler/161/ bikmaz.htm adresinden erişildi.

[6] Buyukozturk, S. (2019) Data analysis Handbook for social Sciences, Pegem Publications, 23. Printing, Ankara.

[7] Carron, A. V., Colman, M. M., Wheeler, J., ve Stevens, D. (2002). Cohesion and performance in sport: A meta analysis. Journal of Sport and Exercise Psychology, 24(2), 168-188.

[8] Cox, R. (2007). Sport Psychology: Concepts and Applications. NY: McGraw-Hill. 
[9] Dion, K. (2000). Group Cohesion: From "field of forces" to multidimensional construct. Group Dynamics:Theory, Research and Practice, 4,1-7

[10] Durdubas, D. (2013). Determining the Effect of Team Building Intervention on Team Coarseness and Motivational Climate Through Team Goal Setting for One Season. Hacettepe University Health Sciences Institute Unpublished Master's Thesis. Ankara.

[11] Feltz D.L., Short S.E., \& Sullivan P.J. (2008). Self-efficacy in sport: Research and strategies for working with athletes, teams, and coaches. Champaign, IL: Human Kinetics.

[12] Kayıs, A. (2006). Reliability Analysis. (Ed) Şeref Kalaycı, SPSS Applied Multivariate Statistical Techniques, Ankara: Asil Publications.

[13] Loughead, T.M., \& Hardy, J. (2006) Team cohesion: From theory to research to team building. In S. Hanton \& S. Mellalieu (Ed.), Literature reviews in sport psychology (sf. 257-278). Hauppauge, NY: Nova Science Publishers.

[14] Mullen, B., ve Cooper, C. (1994). The relation between group cohesiveness and performance: An integration. Psychological Bulletin, 115, 210-227.

[15] Ocel, H. ve Aydın O. (2009). Relationships between the perception of collective competence, self-efficacy and coarseness in sports teams and their perceptions and expectations of success, Journal of Faculty of Letters, 26 (2), 155-174.

[16] Senemoglu, N. (1997). Development from learning and teaching theory to practice. Ankara: Ertem Printing.

[17] Spink, K.S.,(1990). Group Cohesion and Collective Efficacy of Volleyball Teams, Journal of Sport and Exercise Psychology, 12(3), 301-311.

[18] Widmeyer, W. N., Silva, J. M., \& Hardy, C. J. (1991). The nature of group cohesion in sport teams: a phenomenological approach. In Association for the Advancement of Applied Sport Psychology Conference, Colorado Springs, CO.

[19] Usher L.E., Pajares F. (2008). Sources of Self-Efficacy in School: Critical Review of the Literature and Future Directions, Review of Educational Research, 78(4), 751-796.

[20] Yesilay, A; (2010), Generalized Autonomy Expectation, İnternet adresi; http://userpage.fu-berlin.de/ health/turk.ht $\mathrm{m}$, Erişim tarihi:02.07.2010.

[21] Yıldırım F. ve İlhan Ö.İ. (2010). Genel Özyeterlilik Ölçeği Türkçe Formunun Geçerlilik ve Güvenilirlik Çalışması, Türk Psikiyatri Dergisi, 21(4), 301-308. 